\title{
Use of Dietary Yeast and its Products in the Feeding Regime of Meat Type Goats
}

\author{
Memoona Nasir ${ }^{1}$ and Kashif Ishaq ${ }^{2 *}$ \\ ${ }^{1}$ Department of Zoology, PMAS-Arid Agriculture University, Pakistan \\ ${ }^{2}$ Department of Livestock Production and Management, PMAS-Arid Agriculture University, Pakistan
}

Received: 眥 April 19, 2018; Published: 跙 May 01, 2018

*Corresponding author: Kashif Ishaq, Department of Livestock Production and Management, PMAS-Arid Agriculture University, Rawalpindi, Pakistan

\begin{abstract}
All around the world, sheeps and goats play an important role in small scale farming systems. Goat farming is very beneficial from economic point of view. It provides many products but meat and milk are the major products. Goat meat has low level of calorie, fat and cholesterol so it is a healthy substitute to beef and lamb. Moreover goats also use extensively to provide milk for human consumption. It is easier to digest than cow's milk because it has smaller fat globules than cow's milk. In order to support metabolic process all living organisms require essential nutrients, to keep themselves alive so variations in animal diets may improve both the quantity and quality of the final products. In recent years, yeasts are gaining popularity in fattening system as a probiotics.

Since yeast is robust with high viability under a range of environmental conditions and can be culture very easily so yeast cultures are more commonly used as a feed supplements in livestock feeding systems. These cultures have positive impact on microbial population in gastrointestinal tract and they increase the beneficial activities associated with these microorganisms that has indirect impact on animal performance. Saccharomyces cerevisiae and Aspergillusoryza are the most important yeast products and they are very significant for the manipulation of rumen metabolism.

It is stated by most of the researchers that yeast culture supplementation has positive impact on carcass characteristics, nutrient digestibility, feed intake and the growth performance of the goats in cost effective way but on the other hand some of the scientists do not support that results and they concluded that yeast supplementation in the diet of goats and other ruminants do not have any significant influences on animal performance, carcass characteristics and other features. Step by step, this paper will make the detail evaluation of the use of dietary yeast and its product in the feeding regime of meat type goats, impact of yeast on goat physiognomic features such as growth performance, feed efficiency, digestibility and meat quality.
\end{abstract}

Keywords: Goat farming; Feeding systems; Yeast products; Yeast culture; Nutrient digestibility; Growth performance; Carcass traits; Meat quality

\section{Introduction}

Agriculture is the backbone of Pakistan's economy and improvement in this sector is essential for the development of country. This sector contributes 19.82 percent to the Gross Primary Production (GDP), provides employment to 42.3 percent people in the country, provide food to the population and many other products. This sector includes many sub-sectors but main sub-sector is livestock in this sector. About 58.55 percent is the contribution of this sub-sector to agriculture value added and to national GDP its share is 11.8 percent and gross value addition increased from Rs.778.3 billion to Rs. 801.3 billion. Livestock animals produce milk, meat, wool, bones, fat, skin etc. But milk and meat are the major harvests [1]. About 30-35 M people in the country are associated with livestock related activities and they earn 30-40 percent of their income from this sub-sector [2].

In livestock, Small ruminants (goats and sheep) preferred over large ruminants because of their high productive potential and small size [3].Sheeps and goats are the earliest animals to be domesticated. They can survive on pastures that cannot be used by 
other livestock and they can tolerate the period of drought better than any other livestock. Especially, goats are capable to tolerate the water deficiency and even limited amount of fodder is enough or them to survive [4]. After china and India, our country is the third largest goat keeping country in the world [5]. There is total 68.4 million goat population in country and Punjab is the province that has highest goat population as given in Figure 1 [6]. Goats in the country produce 845 million liters of milk and have share to 671 thousand tonnes of mutton produce by small ruminants [1]. More than 25 recognized goat breeds exist in Pakistan [7] along with two wild relatives of goats that are Markhor and Ibex [8].

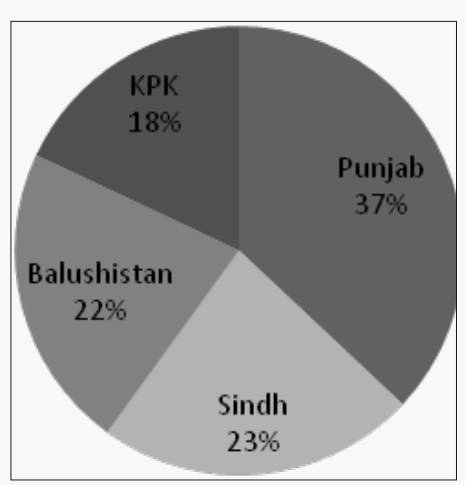

Figure 1: Population of goats in provinces of Pakistan. Source: ACO (2006)

\section{Goat farming and its products}

All around the world, sheeps and goats play an important role in small scale farming systems. Goat farming is very beneficial from economic point of view. It provides many products but meat and milk are the major products. Food is necessary to stay alive. Among the humans religion is the major factor that influences the choices of food. Muslims and Jews are very careful and they only allowed eating halal food such as halal meat and drinks. Halal meat is a meat that obtained from the animals such as goats, sheeps, cattle and chicken that slaughtered under the rules provided by Islam and halal meat do not contain any ingredient from haram animals such as pig etc. [9].

Goat meat is highly nutritious, internationally it is known as lean red meat [10-12]. In most of the developing countries goat meat is very important source of protein [13]. It is one of the staple meats in human diet. It comprises 63 percent of all red meat that consumed worldwide [14]. Goat meat is healthy and better substitute as compared to other red meats. It contains low level of calorie, fat, cholesterol (Table 1) [15] buthas high levels of iron and it becomes more popular widely among general population so its demand (as alternative low fat meat) increasing continuously [16]. However, goat meat has necessary fatty acids this is because of the fact that goats deposit greater level of polyunsaturated fatty acids than other ruminants $[17,18]$. Moreover, goats extensively use for the provision human consumable milk [19]. Pakistan is the fourth largest milk producing country in the world.
Table 1: nutritive comparison of goat meat with other meat.

\begin{tabular}{|c|c|c|c|c|c|}
\hline $\begin{array}{c}\text { Cooked/ } \\
\text { roasted Per 3 oz }\end{array}$ & $\begin{array}{c}\text { Protein } \\
\text { (g) }\end{array}$ & $\begin{array}{c}\text { Sat fat } \\
\text { (g) }\end{array}$ & $\begin{array}{c}\text { Fat } \\
\text { (g) }\end{array}$ & $\begin{array}{c}\text { Cholesterol } \\
\text { (mg) }\end{array}$ & Calories \\
\hline Goat & 23 & .79 & 2.8 & 63.8 & 122 \\
\hline Lamb & 24 & 2.9 & 8.1 & 78.2 & 175 \\
\hline Chicken(skinless) & 25 & 1.7 & 6.3 & 76.0 & 162 \\
\hline Beef & 25 & 3.0 & 7.9 & 73.1 & 179 \\
\hline Pork & 25 & 2.9 & 8.2 & 73.2 & 180 \\
\hline
\end{tabular}

Source: USDA (2001)

Approximately 0.7 million tonnes of the milk is produced by goats in Pakistan which is Only 0.2 percent of the total milk produced in the country as shown in Table 2 [20]. Scanty information is available regarding the physiological and chemical facts about the unique quality of goat milk. It contains greater level of short and medium chain fatty acids; these fatty acids are remedial against many diseases and disorders [21]. Goat milk is easier to digest than cow's milk because it possesses smaller fat globules than cow's milk [22]. Goat's milk helps to prevent iron deficiency and bone demineralization because it contains higher vitamins and mineral contents than human milk as shown in Table 3 [23].

Table 2: Amount of milk produced in top ten countries.

\begin{tabular}{|c|c|}
\hline Country & Goat milk ( million MT) \\
\hline India & 4.0 \\
\hline Bangladesh & 2.2 \\
\hline Sudan & 1.5 \\
\hline Pakistan & 0.7 \\
\hline Spain & 0.6 \\
\hline France & 0.6 \\
\hline Greece & 0.5 \\
\hline Iran & 0.4 \\
\hline Somalia & 0.4 \\
\hline China & 0.3 \\
\hline
\end{tabular}

Source: FAOSTAT (2008)

Table 3: Comparison of vitamins and minerals in human and goat milk.

\begin{tabular}{|c|c|c|}
\hline Composition & Goat milk & Human milk \\
\hline Vitamin B12 & 0.64 & 0.97 \\
\hline Vitamin B6 & 0.5 & 0.093 \\
\hline Vitamin A & 548 & 670 \\
\hline Vitamin E & -- & 2.3 \\
\hline Vitamin Dmg/L & 0.6 & 0.55 \\
\hline Vitamin K & 12 & 2.1 \\
\hline Ascorbic acid & 12.6 & 40 \\
\hline Riboflavin & 1.4 & 0.35 \\
\hline Panthothenic acid & 3.0 & 1.8 \\
\hline Niacin & 2.7 & 1.5 \\
\hline
\end{tabular}




\begin{tabular}{|c|c|c|}
\hline Thiamin & 0.5 & 0.21 \\
\hline $\mathrm{Ca} \mathrm{mg/L}$ & 1304 & 280 \\
\hline $\mathrm{Mg}$ & 136 & 35 \\
\hline $\mathrm{K}$ & 1996 & 525 \\
\hline $\mathrm{Fe}$ & 0.5 & 0.3 \\
\hline $\mathrm{P}$ & 1080 & 140 \\
\hline $\mathrm{Na}$ & 488 & 180 \\
\hline $\mathrm{Cl}$ & 1566 & 420 \\
\hline $\mathrm{Cu}$ & 0.23 & 0.25 \\
\hline $\mathrm{Zn}$ & 2.9 & 1.2 \\
\hline
\end{tabular}

yeast products are produced by many companies with variable trade names but a limited number of YP have been evaluated under controlled research studies. Saccharomyces cerevisiae and Aspergillusoryza are the yeast products and they are very important for the manipulation of rumen metabolism. Agarwal et al. [32] performed an experiment in which they use different strains of S. cerevisiae as a microbial feed additive and they reported that $S$. cerevisiae strain NCDC 49 is the best strain because it can tolerate the stressed conditions in gastrointestinal tract of animal. Yeast strains differ in their ability to stimulate the ruminal bacteria. It was reported by Dawson and Hopkins [33] that out of 50 only 7 strains are capable to stimulate the growth of bacteria that digest fiber from the rumen so care should be taken to select S.cerevisiae strains for use in yeast culture preparation of ruminants. Baker's yeast strains and Brewer's yeast strains vary in their capabilities to stimulate the critical groups of ruminal microorganisms and former strain has limited capability in this kind of stimulation [34]. According to Zelenak et al. [35] ruminal hemicellulose digestibility increase by the addition of live yeast product Yea-Sacc to the diet when substrate contains 20 percent and 50 percent barely in vitro.

\section{Feeding system and yeast addition}

Feed is the essential component in livestock farming and different experiments have been conducted to improve the quality of feeds given to the ruminants. Feed additives has positive influence on digestion rate and leads to the better growth performance, this is because of the fact that feed additives increase gut health of the animals [36]. As probiotics, yeasts are gaining popularity in fattening system. It is robust with high viability under a range of environmental conditions and can be culture very easily [37]. Many researchers proposed that supplementation of yeast culture in the diet up surge feed intake [38,39], nutrient digestibility [40] and the rate of growth [41] in cost effective way [42]. According to some investigators addition of yeast in the feed of meat producing ruminants leads to the variable growth responses that vary from no significant rise in average daily gain to an increase of greater than 20 percent. In this case the average daily gain was 8.7 percent [43].

There are various feeding systems such as high input feeding system, extensive feeding system, intensive feeding system, fodder based feeding system and grain based feeding system, use of yeast as a probiotic in these systems results in variable responses for example Shankpal et al. [44] conducted an experiment in India on Surti goat Kids. In their experiment, these scientists raised their goats under total mixed ration based feeding system with the supplementation of yeast to access its effect on growth performance, digestibility, feed conversion efficiency and feed intake of these kids. Total mixed ration (TMR) based feeding system actually involve mixing of all feedstuffs in an equal ration with respect to their nutritive value so this system supplies an ample amount of nutrition and energy to the animals which enable them to attain maximum performance. These Indian scientists concluded that this inclusion of yeast in feeding system had positive impact on all the 
described parameters and also results in 6.66 percent lower feed cost in the experimental group than control group [44].

Furthermore, many scientists conducted an experiments on different animals raised under intensive feeding system for example Kawas et al. conducted an experiment on Pelibuey male lambs in mexico. These lambs were raised under intensive feeding system with the supplementation of yeast culture and sodium bicarbonate in their finishing diets to check its effect on growth rate and other parameters. At the end of the experiment these scientists concluded that supplementation of yeast in the finishing diet of intensively fed lambs has no significant impact on growth rate, digestibility and rumen $\mathrm{pH}$ [45]. Outcomes of this study were similar with the work of some other scientists who concluded that the addition of yeast in the finishing diets of intensively fed bulls has no impact on their growth rate [46-48]. Rearing of the kids under grain based feeding system is helpful to fulfill their nutritional requirements which have positive impact on their growth. However supplementation of diet with yeast enhances these beneficial impacts. According to Nisbet et al. [49] for the fattening ruminants addition of malate and yeast in grain based diets has much more beneficial influences and important for animal health [49].

\section{Effect of yeast on the digestibility and feed intake}

Supplementation of yeast in feed improves the digestibility of nutrients and results in higher production of carboxymethyl cellulase activity in rumen [50,51]. Yeast culture leads to the beneficial changes in the digestion by positively influencing the ruminal fermentation. In India it is demonstrated by Kumar et al. [52] that yeast culture has positive impact on feed intake and process of digestion in rumen. On the other hand, some scientists conducted an experiment in Turkey to demonstrate the variations in ruminal fermentation and nutrient degradability of some feedstuffs due to the supplementation of live yeast culture in diet of yearling lambs. In their study they use corn DDGS as a protein source, barley grain as an energy source and wheat straw as roughage and they concluded that live yeast addition in diet has no impact on dry matter (DM) degradability but it reduce the degradability of corn dried distillers grains with soluble (DDSG) in rumen.

Better feed intake has positive impact on animal production [53]. Within 6-8 hrs after meal yeast culture supplementation stimulate the higher degradation of solid feeds and higher intake of dry matter. Dry matter intake is the part of initial rate of fiber digestion. It is reported that yeast culture supplementation increase dry matter intake in some studies $[40,54]$ but not in other studies [55,56]. Dawson et al. [57] demonstrated that yeast culture supplementation has pivotal role in digestion in those animals that maintained at high forage diets In South Brazil, Lima et al. [58] analyze the impact of inactive dry yeast (S. cerevisiae) from sugar cane as protein source on dairy goat performance and they reported that dry yeast supplementation in goat's diet cause lower intake of dry matter and organic matter intake as compare to the soybean + dry yeast diet. This is because of the fact that dry yeast has very fine texture and unusual aroma from sugar cane that cause decrease in the intake of dry matter. Williams [59] confirmed that the quantity of rumen cellulolytic bacteria was amplified by yeast supplementation, exclusively in high concentrate diets.

\section{Effect of yeast addition on growth performance}

Many studied demonstrate that diet supplementation with yeast improves the growth performance in finishing lambs [60], calves [61] and bulls [46,47]. According to Haddad et al. [62] yeast supplementation in fattening sheep diet increase the weight gain. In Turkey, Bugdayci et al. [63] conducted an experiment on Saanen male kids and they reported that live yeast supplementation do not influence the live weight gain in goats but some researches do not support this idea $[64,65]$. However, Mikulecet al. [66] stated that there is no influence of live yeast supplementation on weight and weight gain in lambs. Titi et al. [67] performed an experiment in Jordanand demonstrated that live weight gain and live weight were not affected by the yeast culture supplementation in both awassi lambs and Shami goat kids.

Abou-ward [68] conducted an experiment on lambs and he find out that in average daily gain and dry matter intake significant upsurge occur in lambs as a result of feeding on the ration that contain at least 0.1 percent yeast culture. Rise in dry matter intake was because of the stimulation by cellulolytic bacteria [29,30,54,69]. Some Brazilian investigators reported that supplementation of live yeast never influence lamb performance such a dry matter intake, daily live weight gain, total live weight gain and final live weight [70]. However, it was also observed that the addition of 2.5 to $5 \mathrm{~g}$ of commercial yeast in the diet of Nubian goats fed sorghum (whole plant) has significant impact on daily live weight gain [71].

\section{Effect of yeast addition on slaughter and carcass traits}

Table 4: Carcass characteristics of Awassi lambs and Shami goat kids as influenced by yeast culture (YC) addition in diet.

\begin{tabular}{|c|c|c|c|c|}
\hline \multirow{2}{*}{} & \multicolumn{2}{|c|}{ Kids } & \multicolumn{2}{c|}{ Lambs } \\
\cline { 2 - 5 } & C & YC & C & YC \\
\hline Animal in each group Features & 6 & 6 & 6 & 6 \\
\hline Fasting weight* $(\mathrm{kg})$ & 37.7 & 38.0 & 42.3 & 42.1 \\
\hline LHKSLS $^{* *}$ weight $(\mathrm{kg})$ & 2.1 & 2.1 & 1.5 & 1.7 \\
\hline HSF*** $^{*}$ weight $(\mathrm{kg})$ & 5.6 & 5.9 & 8.1 & 8.7 \\
\hline Dressing proportion & 0.546 & 0.562 & 0.526 & 0.478 \\
\hline Hot carcass weight $(\mathrm{kg})$ & 21.1 & 21.8 & 23.0 & 20.8 \\
\hline $\begin{array}{c}\text { Empty digestive tract } \\
\text { weight }(\mathrm{kg})\end{array}$ & 3.6 & 3.2 & 2.1 & 2.5 \\
\hline Total fat weight**** $(\mathrm{kg})$ & 0.40 & 0.50 & 0.05 & 0.10 \\
\hline
\end{tabular}

C: control group (without yeast addition).

YC: treatment group (with yeast culture supplementation).

*Average weight of 6 animals.

**LHKSLS: weight of liver+heart+kidneys+spleen+lungs+sweetbread. 
***HSF: weight of head+skin+feet.

**** fat of heart+kidney+pelvic.

Source: Titi [67].

Particularly with reference to small ruminants scarce work had been published regarding the impact of yeast culture supplementation on carcass characteristics. Titi et al. [67] reported that yeast culture supplementation has no impact on cold dressing proportion and hot carcass weight of Shami goat kids but yeast culture supplementation decrease the cold dressing proportion, overall muscle/bone ratio and hot carcass weight in lambs. Carcass weight reduced in lambs because of the enlargement of the digestive tract due to higher dry matter intake (Table 4). It is demonstrated by kawas et al. [60] that in the lambs that were fed with high grain finishing diet, there is no impact of yeast culture supplementation on dressing proportion and chilled carcass weight of these lambs.

Similarly, Freitas et al. [72] reported that in different breeds of goats inclusion of dry yeast has no influence on hot and cold carcass weight, true carcass yield and carcass compactness index. According to Bugdayci et al. [63] live yeast supplementation in diet has no influence on hot and cold carcass yield in goats as shown in (Table 5) [63]. Similarly, investigators failed to find out any positive impact of yeast culture supplementation on carcass characteristics and composition in bulls or steers [73]. In the same way, some scientists reported that supplementation of S.cerevisiae results in the improvement of lamb fattening performance without any significant alteration in carcass traits [74].

Table 5: Impact of yeast supplementation on Saanen male kid's carcass yields and characteristics.

\begin{tabular}{|c|c|c|c|c|}
\hline \multicolumn{5}{|c|}{ Dietary treatments } \\
\hline & C & S & S+LYS & p \\
\hline $\begin{array}{c}\text { Cold carcass yield } \\
\%\end{array}$ & $46.53 \pm 0.71$ & $43.04 \pm 1.21$ & $46.30 \pm 1.23$ & 0.060 \\
\hline $\begin{array}{c}\text { Cold carcass weight } \\
(\mathrm{kg})\end{array}$ & $12.03 \pm 0.72$ & $10.63 \pm 1.24$ & $12.16 \pm 0.54$ & 0.447 \\
\hline Hot carcass yield \% & $47.44 \pm 0.62$ & $44.28 \pm 1.13$ & $46.76 \pm 1.31$ & 0.102 \\
\hline $\begin{array}{c}\text { Hot carcass weight } \\
(\mathrm{kg})\end{array}$ & $12.26 \pm 0.72$ & $10.93 \pm 1.26$ & $12.28 \pm 0.54$ & 0.512 \\
\hline
\end{tabular}

$\mathrm{p}<0.05$

C: Control group

S: Group served with sucrose added diet

S+LYS: Group served with sucrose and live yeast culture added diet

Source: Bugdayci [63].

\section{Effect of yeast addition on meat quality}

Growth rate of goat population is high (3.5 percent per annum) because of preference of goat meat [75]. Meat quality is the standard term that uses to describe the properties and perceptions of meat. Goat meat is highly nutritious internationally it is known as lean red meat [10-12]. It has course texture, dark red colour and as compare to lamb meat it has different flavor and aroma, characteristically [76]. Sethy et al. [77] observed that redness and tenderness of meat increase but shear force value decrease as a result of addition of 0.3 mg Seas selenium yeast and 100 IU vitamin E in goat diet. Similarly it was proposed by Morrissey et al. [78] that supplementation of diet with selenium yeast results in the rise of $\alpha$-tocopherol in muscles but decrease the chances of lipid oxidation in muscles.

Likewise, Rufino et al. [79] reported that the addition higher level of inactive dry yeast in the diet of lambs improves the meat quality and carcass characteristics by decreasing the level of intramuscular and subcutaneous fat but by increasing the level of meat crude protein and ash concentration. Dry yeast addition in the diet of different goat breed does not influence the values of cooking loss and shear force value [72]. Some investigators concluded that quality of meat improved and shelf life extend as a result of supplementation of diet with Selenium yeast and vitamin $\mathrm{E}$ because it enhanced antioxidant status in the muscle [80]. Effect of yeast supplementation on lamb meat quality has also been demonstrated by Titi et al. [67] who concluded that the addition of live cultures of S.cerevisiae yeast in diet leads to the significant change in the chemical composition of meat.

\section{Conclusion}

All the yeast culture supplementation strategies are not identical in their efficiency because the influences of yeast culture supplementations on animal efficiency are strain dependent so the results of supplementations may vary considerably. However, it is concluded that the addition of yeast in the diet of goats and other ruminants is beneficial. Yeast culture supplementation is very convenient strategy that positively modifies the microbial actions, digestive tasks in rumen, meat quality and fattening performance in goats but still it is prerequisite to conduct more experiments under different feeding circumstances and in extended fattening episodes to clarify the beneficial influences of yeast addition in the diet of goats.

\section{References}

1. Economic Survey of Pakistan (2015-16) Government of Pakistan, Finance Division, Economic Adviser's Wing, Islamabad.

2. Riaz K (2008) A case study of milk processing: The Idara-E-Kissan Cooperative. The Lahore Journal of Economics 13(1): 87-128.

3. Khan MFU (2014) Country report-Pakistan. Asian-Australasian dairy goat network p.66.

4. Upadhyay BA (2003) Goat breeding strategy with reference to commercial goat production. Dept. of Animal Science and Dairy Science, Mahatma Phule Krishi Vidhyapeeth, Rahuri, Maharastra. State level workshop on recent advance in goat rearing, 29-30 Dec.

5. FAOSTAT (2013) Food and Agriculture Organization of United Nations. 
6. ACO (2006) Livestock Census 2006. Government of Pakistan, Statistics Division, Agricultural Census Organization, Gurumangat Road, GulbergIII, Lahore, Pakistan.

7. Hasnain HU (1985) Sheep and Goats in Pakistan.FAO Animal Production and Health.FAO, Rome p.56.

8. Khan MS, MA Khan, S Mahmood (2008) Genetic resources and diversity in Pakistani goats. International Journal of Agriculture and Biology 10(2): 227-231.

9. Twaigery S, D Spillman (1989) An Introduction to Muslim Dietary Law. Food Tech 43(2): 88-90.

10. Hogg BW, GJK Mercer, BJ Mortimer, AH Kirton, DM Duganzich (1992). Carcass and meat quality attributes of commercial goats in New Zealand. Small Rumin Res 8: 243-256.

11. Babiker SA, IA El-Khider, SA Shafie (1990) Chemical composition and quality attributes of goat meat and lamb. Meat Sci 28(4): 273-277.

12. Webb EC, NH Casey, L Simela (2005) Goat meat quality. Small Rumin Res 60(1-2): 153-166.

13. Casey NH (1992) Goat meat in human nutrition. Research gate 2(2): 581-598.

14. Anonymous (2005) National Agricultural Statistics Service. Livestock Slaughter. Annual Summary. United States Department of Agriculture.

15. USDA (2001) Nutrient Database for Standard Reference: Nutritional value of goat.

16. Anonymous (2008-09) Pakistan Economic Survey 2008-09. Government of Pakistan, Finance Division, Economic Advisor s Wing Islamabad.

17. Mahgoub 0, AJ Khan, RS Al-Maqbaly, JN Al-Sabahi, K Annamalai, et al (2002) Fatty acid composition of muscle and fat tissues of Omani Jebel Akhdar goats of different sexes and weights. Meat Sci 61(4): 381-387.

18. Banskalieva V, T Sahlu, AL Goetsch (2000) Fatty acid composition of goat muscles and fat depots: a review. Small Rumin Res 37(3): 255-268.

19. Harren RV (1994) The Science of animal agriculture. Delmar Publisher Inc. Albany, New York.

20. FAOSTAT (2008) Food and Agriculture Organization of United Nations.

21. Haenlein GFW (2004) Goat milk in human nutrition. Small Rum Res 51(2): 155-163.

22. Fevrier C, J Mourot, Y Jaguelin, A Mounier, Y Lebreton (1993) Comparative digestive utilization of UHT goat and cow's milk: nutritional effects of galation-use of a swine model. Lait 73: 581-592.

23. O'Connor DL (1994) Folate in goat milk products with reference to other vitamins and minerals : A review. Small Rumin Res 14: 143-149.

24. Bergen W (1963) Wool hand book ( $3^{\text {rd }}$ edn.), Vol 1 (Inter Science Publishers, London).

25. Shakyawar DB, ASM Raja, A Kumar, PK Pareek, SA Wani (2013) Pashmina fiber-production, characteristics and utilization. Indian J Fiber Text Res 38: 207-214.

26. Mc Grogor BA (2003) Australian J Exp agric 43: 1199.

27. Adams AL, B Harris, HH Van Horn, CJ Wilcox (1995) Effects of varying forage types on milk production responses to whole cottonseed, tallow, and yeast. J Dairy Sci 78(3): 573-581.

28. Nocek JE, WP Kautz, JAZ Leedle, E Block (2003) Direct-fed microbial supplementation on the performance of dairy cattle during the transition period. J Dairy Sci 86(1): 331-335.
29. Putnam DE, CG Schwab, MT Socha, NL Whitehouse, NA Kierstead, et al. (1997) Effect of yeast culture in the diets of early lactation dairy cows on ruminal fermentation and passage of nitrogen fractions and amino acids to the small intestine J Dairy Sci 80(2): 374-384.

30. Piva G, S Belladonna, G Fusconi, F Sicbaldi (1993) Effects of yeast on dairy cow performance, ruminal fermentation, blood components, and milk manufacturing properties. J Dairy Sci 76(9): 2717-2722.

31. Dawson KA, Eds TP, Lyons, KA Jacques (2000) In Biotechnology in feed industry. Proceedings of the 16th Annual Symposium. Nottingham University Press, Lough borough, Leies, UK pp. 473-488.

32. Agarwal N, DN Kamra, LC Chaudhary, A Sahoo, NN Pathak (2000) Selection of Saccharomyces cerevisiae strains for use as a microbial feed additive. Letters in Appl Microbiol 31(4): 270-273.

33. Dawson KA, DM Hopkins (1991) Differential effects of live yeast on the cellulolytic activities of anaerobic ruminal bacteria. J Anim Sci 69(1): 531.

34. Newbold CJ, RJ Wallace, FM McIntosh (1996) Mode of action of the yeast Saccharomyces cerevisiae as a feedadditive for ruminants. Br J Nutr 76(2): 249-261.

35. Zelenak I, D Jalc, V Kmet, P Siroka (1994) Influence of diet and yeast supplement on in vitro ruminal characteristics. Anim Feed Sci Technol 49(3-4): 211-221.

36. Kawakami SI, T Yamada, N Nakanishi, Y Cai (2010) Feeding of lactic acid bacteria and yeast on growth and diarrhea of Holstein calves. J Anim and Vet Advances 9(7): 1112-1114.

37. Tripathi MK, SA Karim, OH Chaturvedi, DL Verma (2008) Effect of different liquid cultures of live yeast strains on performance, ruminal fermentation and microbial protein synthesis in lambs. J Anim Physio Anim Nutr 92(6): 631-639.

38. Ayad MA, B Benallou, MS Saim, MA Smadi, T Meziane (2013) Impact of Feeding Yeast Culture on Milk Yield, Milk Components, and Blood Components in Algerian Dairy Herds. J Vet Sci Technol 4(135): 2.

39. Robinson PH, LJ Erasmus (2009) Effects of analyzable diet components on responses of lactating dairy cows to Saccharomyces cerevisiae based yeast products: A systematic review of the literature. Anim Feed Sci Technol 149(3-4): 185-198.

40. Wohlt JE, AD Finkelstein, CH Chung (1991) Yeast culture to improve intake, nutrient digestibility, and performance by dairy cattle during early lactation. J Dairy Sci 74(4): 1395-1400.

41. Lascano GJ, GI Zanton, MF Suarez-Mena, AJ Heinrichs (2009) Effect of limit feeding high and low-concentrate diets with Saccharomyces cerevisiae on digestibility and on dairy heifer growth and first-lactation performance. J Dairy Sci 92(10): 5100-5110.

42. Hutjens MF (2003) Economics of feed additives. Penn State Dairy Cattle Nutrition Workshop.

43. Dawson KA (2002) a Manipulating Rumen Microbial Population to Improve Animal Productivity. Proceedings Intermountain Nutrition Conference, Animal Nutrition, Health and Profit, Utah State University, USA, p. 1-22.

44. Shankhpal S, S Parnerkar, BM Bhanderi (2016) The Effect of Feeding Bypass Fat and Yeast (Saccharomyces cerevisiae) Supplemented Total Mixed Ration on Feed Intake, Digestibility, Growth Performance and Feed Conversion Efficiency in Weaner Surti Kids.

45. Kawas JR, RG Castillo, HF Duarazo, FG Cazares, JFGH Vidal, et al. (2007) Effects of sodium bicarbonate and yeast on nutrient intake, digestibility, and ruminal fermentation of light weight lambs fed finishing diets. Small ruminant research 67(2): 147-156. 
46. Mutsvangwa T, IE Edwards, JH Topps, GF Paterson (1992) The effect of dietary inclusion of yeast culture (Yea-Sacc) on patterns of rumen fermentation, food intake and growth of intensively fed bulls. Animal Science 55: 35-40.

47. El Hassan, SM, CJ Newbold, IE Edwards, JH Topps, RJ Wallance (1996) Effect of yeast culture on rumen fermentation, microbial protein flow from the rumen and live-weight gain in bulls given high cereal diets. Anim Sci 62(1): 43-48.

48. Beauchemin, K.A., W. Z. Yang, D. P. Morgavi, G. R. Ghorbani, W. Kautz, and J. A. Z. Leedle. 2003. Effects of bacterial direct-fed microbial and yeast on site and extent of digestion, blood chemistry, and sub-clinical ruminal acidosis in feedlot cattle. J. Anim. Sci. 81: 1628-1640.

49. NisbetDJ, SA Martin (1991) Effect of a Saccharomyces cerevisiae culture on lactate utilization by the ruminal bacterium Selenomonasruminantium. J Anim Sci 69(11): 4628-4633.

50. Maurya MS, R Singh, NN Pathak, DN Kamra (1993) Effect of feeding live yeast (Saccharomyces cerevisiae) on nutrient digestibility in goats. In: Proceedings of Sixth Animal Nutrition Research Workers Conference, Bhubaneswar. 13-16: 142.

51. Garg DD (2008) Efficiency of utilization of leguminous straw based complete feed blocks alone and in combination with probiotics (Saccharomy cescerevisiae) in ration of sheep. Ph.D. Thesis, Rajasthan Agricultural University, Bikaner, Rajasthan, India.

52. Kumar U, VK Sareen, S Singh (1997) Effect of yeast culture supplement on ruminal microbial populations and metabolism in buffalo calves fed a high roughage diet. J Sci Food Agric 73(2): 231-236.

53. Inal F, E Gurbuz, B Coskun, MS Alatas, OB Citil, et al. (2010) The Effects of Live Yeast Culture (Saccharomyces cerevisiae) on Rumen Fermentation and Nurtient Degradibility in Yearling Lambs. Food and Agriculture of United Nations 16 (5): 799-804.

54. Williams PEV, CAG Tait, GM Innes, CJ Newbold (1991) Effects of the inclusion of yeast culture (Saccharomycescerevisiae plus growth medium) in the diet of dairy cows on milk yield and for age degradation and fermentation patterns in the rumen of steers. J Anim Sci 69: 30163026 .

55. Kung L, RE Muck (1997) Animal response to silage additives. Proceedings of the conference on Silage: Field to feedbunk. North American Conference Hershey 99: 200-212.

56. Arambel MJ, B Kent (1990) Effect of yeast culture on nutrient digestibility and milk yield response in early to mid-lactation dairy cows. J Dairy Sci 73(6): 1560-1563.

57. Dawson KA, J Tricarico (2002) The evolution of yeast cultures-20 years of research. In: Navigating from Niche Markets to Mainstream. Proceedings of Alltech's European, Middle Eastern and African Lecture Tour, pp. 26-24

58. Lima SLD, CR Alcalde, HS Freitas, BSDL Molina, FDAFD Macedo, et al. (2012) Performance of dairy goats fed diets with dry yeast from sugar cane as protein source. R Bras Zootec 41(1): 232-236.

59. Williams PEV (1989) The mode of action of yeast culture in ruminal diets. A review of the effect on rumen fermentation patterns. Biotechnology in the feed industry. Alltech Tech. Publishers. Nicholasville, Kentuky, USA, p. 65 .

60. Kawas JR, RG Castillo, FG Cazares, HF Durazo, EO Saenz, et al. (2007) Effects of sodium bicarbonate and yeast on productive performance and carcass characteristics of light-weight lambs fed finishing diets. Small Rumin Res 67(2-3): 157-163.

61. Cole NA, CW Purdy, DP Hutcheson (1992) Influence of yeast culture on feeder calves and lambs. J Anim Sci 70(6): 1682-1690.
62. Haddad SG, SN Goussous (2004) Effects of yeast culture supplementation on nutrient intake digestibility and growth performance of Awassi lambs. Anim Feed Sci Technol 118(3-4): 343-348.

63. Bugdayci KE, MN Oguz, FK Oguz, MK Albay, J Oner (2016) Effects of live yeast culture addition into sucrose supplemented diet on fattening performance, some blood and histological parameters in Saanen male kids fed without forage. Ankara Univ Vet Fak Derg 63(2): 163-170.

64. Ozsoy B, S Yalcın, Z Erdogan, Z Cantekin, T Aksu (2013) Effects of dietary live yeast culture on fattening performance on some blood and rumen fluid parameters in goats. Rev Med Vet 164: 263-271.

65. Kamal R, T Dutta, M Singha, DN Kamrab, M Patel, et al. (2013) Effect of live Saccharomyces cerevisiae (NCDC-49) supplementation on growth performance and rumen fermentation pattern in local goat. J Appl Anim Res 41(3): 285-288.

66. Mikulec Z, T Masek, B Habrunand, H Valpotic (2010) Influence of live yeast cells (Saccharomyces cerevisiae) supplementation to the diet of fattening lambs on growth performance and rumen bacterial number. Veterinarski arhiv 80(6): 695-703.

67. Titi HH, RO Dmour, AY Abdullah (2008) Growth performance and carcass characteristics of Awassi lambs and Shami goat kids fed yeast culture in their finishing diet. Anim Feed Sci and Tech 142(1-2): 33-43.

68. Abou ward GA (2001) Supplementing finishing rations with yeast culture (Yea-Sacc 1026) and its influence on lamb's performance. J Agric Sci Mansoura Univ 26 (5): 2677-2686.

69. Erasmus LJ, PM Botha, A Kistner (1992) Effect of yeast culture supplement on production, rumen fermentation duodenal nitrogen flow in dairy cows. J Dairy Sci 75(11): 3056-3065.

70. Issakowicz J, MS Bueno, ACK Sampaio, KMR Duarte (2013) Effect of concentrate level and live yeast (Saccharomyces cerevisiae) supplementation on Texel lamb performance and carcass characteristics. Livestock Sci 155(1): 44-52.

71. Fadel Elseed AMA, MA Rania Abusamra (2007) Effects of supplemental yeast (Saccharomyces cerevisiae) culture on NDF digestibility and rumen fermentation of forage sorghum hay in Nubian goat's kids. Res J Agric Biol Sci 3: 133-137.

72. Freitas HS, CR Alcalde, LSD Lima, FDAFD Macedo, VDP Macedo, et al (2011) Quantitative characteristics of carcass and meat quality of $3 / 4$ Boer+ $1 / 4$

73. Saanen and Saanen goat kids fed diets with dry yeast. Revista Brasileira de Zootecnia 40(3): 630-638.

74. Mir Z, PS Mir (1994) Effect of the addition of live yeast (Saccharomyces cerevisiae) on growth and carcass quality of steers fed high-forage or high-grain diets and on feed digestibility and in situ degradability. J Anim Sci 72(3): 537-545.

75. Payandeh S, F Kafilzadeh (2007) The effect of yeast (Saccharomyces cerevisiae) on nutrient intake, digestibility and finishing performance of lambs fed a diet based on dried molasses sugar beet-pulp. Pak J Biol Sci 10(24): 4426-4431.

76. Anonymous (2010) Economic Survey of Pakistan 2010-11. Government of Pakistan, Economic Affairs Wing, Finance Ministry, Islamabad.

77. Schonfeldt HC, RT Naude, W Bok, SM Van Heerden, R Smit, et al. (1993) Flavor and tenderness related quality characteristics of goat and sheep meat. Meat Sci 34(3): 363-379.

78. Sethy K, AK Garg, SK Mishra, SS Biswal, AK Behera, et al. (2014) Effect of selenium yeast and vitamin $\mathrm{E}$ supplementation on meat quality of male goats (Capra hircus). Meat Sci and Tech 2(4): 74-78. 
79. Morrisey PA, PJA Sheehy, K Galvin, JP Kerry, DJ Buckley (1998) Lipid stability in meat and meat products. Meat sci 49(1): S73-S86.

80. Rufino LDA, OG Pereira, KG Ribeiro, SCV Filho, JCavali, et al. (2013) Effect of substitution of soybean meal for inactive dry yeast on diet digestibility, lamb's growth and meat quality. Small Rumin Res 111(1-3): 56-62.
81. Mitsumoto M, S Ozawa, T Mitsuhashi, K Koide (1998) Effect of dietary vitamin E supplementation for one week before slaughter on drip, color and lipid stability during display in Japanese Black steer beef.Meat Science 49(2): 165-174. (c) (P)

This work is licensed under Creative

Commons Attribution 4.0 License

Submission Link:

Submit Article

DOI: $10.32474 /$ CDVS.2018.01.000108

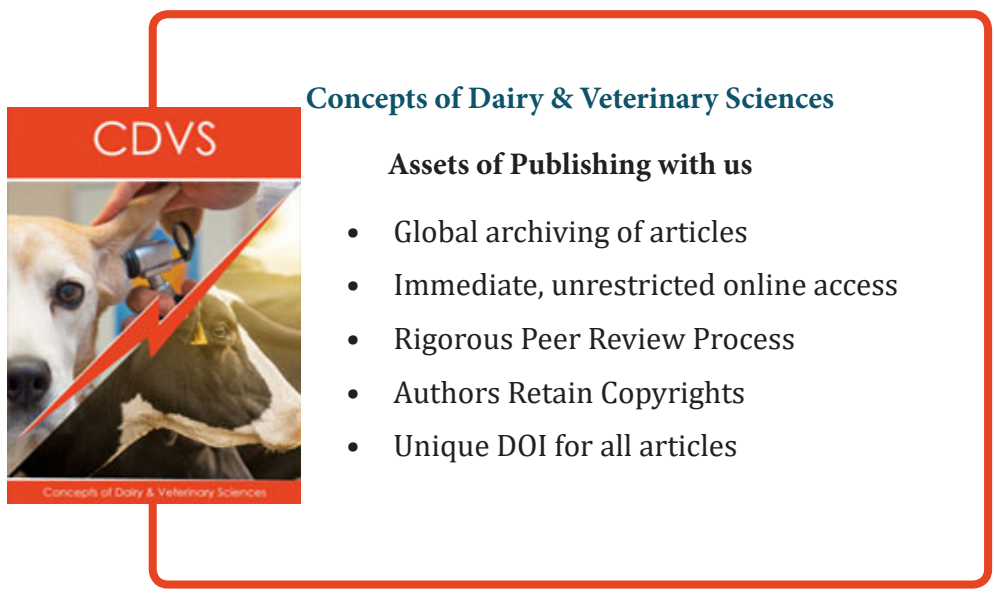

